Georgia State University

ScholarWorks @ Georgia State University

$1-5-2012$

\title{
Competing with Costco and Sam's Club: Warehouse Club Entry and Grocery Prices
}

Charles Courtemanche

University of Louisville, cjcour02@louisville.edu

Art Carden

Rhodes College, cardena@rhodes.edu

Follow this and additional works at: https://scholarworks.gsu.edu/uwrg_workingpapers

\section{Recommended Citation}

Courtemanche, Charles and Carden, Art, "Competing with Costco and Sam's Club: Warehouse Club Entry and Grocery Prices" (2012). UWRG Working Papers. 56.

https://scholarworks.gsu.edu/uwrg_workingpapers/56

This Article is brought to you for free and open access by the Usery Workplace Research Group at ScholarWorks @ Georgia State University. It has been accepted for inclusion in UWRG Working Papers by an authorized administrator of ScholarWorks @ Georgia State University. For more information, please contact scholarworks@gsu.edu. 
Working Paper 2012-1-5

January 2012

\section{Competing with Costco andd Sam's Club: Warehouse Club Entry and Grocery Prices}

Charles Courtemanche Georgia State University

\section{Art Carden}

\section{Rhodes College}


Competing with Costco and Sam's Club: Warehouse Club Entry and Grocery Prices

January 23, 2012

\author{
Charles Courtemanche* \\ Department of Economics, College of Business \\ University of Louisville \\ Louisville, KY 40292 \\ and National Bureau of Economic Research, Cambridge, MA \\ cjcour02@louisville.edu \\ Office: 502-852-4854; Fax: 502-852-7672 \\ Art Carden \\ Department of Economics and Business \\ Rhodes College \\ 2000 N. Parkway \\ Memphis TN 38112 \\ cardena@ rhodes.edu \\ Office: 901-843-3829; Fax: 901-843-3736
}

\begin{abstract}
Prior research shows grocery stores reduce prices to compete with Walmart Supercenters. This study finds evidence that the competitive effects of two other big box retailers - Costco and Walmart-owned Sam's Club - are quite different. Using city-level panel grocery price data matched with a unique data set on Walmart and warehouse club locations, we find that Costco entry is associated with higher grocery prices at incumbent retailers, and that the effect is strongest in cities with small populations and high grocery store densities. This is consistent with incumbents competing with Costco along non-price dimensions such as product quality or quality of the shopping experience. We find no evidence that Sam's Club entry affects grocery stores' prices, consistent with Sam's Club's focus on small businesses instead of consumers.
\end{abstract}

Keywords: Wal-Mart, Walmart, Costco, Sam's Club, warehouse clubs, grocery prices, competition, retail

JEL Codes: L11, L13, L81, R10

*-Corresponding Author. Comments Welcome. Benjamin Anderson, Kenneth Snowden, and seminar participants at the University of Nebraska at Omaha, the University of North Carolina at Greensboro, and the 2010 Southern Economic Association meetings provided useful comments. We are grateful to Keith Becker and Sameer Warraich for excellent research assistance and WalMart's External Reporting Team for directing us to public company financial documents on Sam's Club. Thach Truong, Kelly Gillean, and Dylan Chambers assisted with data collection. Julia Clapper proofread the manuscript. 


\section{INTRODUCTION}

Firms do not compete on price and quantity alone. They also compete by innovating, experimenting, and differentiating their products. In retail, they can compete by changing the mix of distribution services and amenities that accompany the goods being offered as well. This paper presents evidence that incumbent grocers charge higher prices in response to competition from the discount wholesaler Costco. This is consistent with incumbents electing not to compete on price, and instead focusing on appealing to less price sensitive consumers by offering, for instance, higher quality products or a more pleasant shopping experience. The data suggest that Sam's Club, meanwhile, does not affect grocery store prices.

Ellickson (2007:45) points out three major changes in grocery retail during the twentieth century. The first was the rise of the chain store in the early 1900s. The second was the introduction and diffusion of the supermarket in the middle of the century. The third was the "adoption of technology-intensive distribution systems in the 1980s and 1990s" (Ellickson 2007:45). To this we might add a trend that accelerated in the 1990s: expansion by "big box" discounters and wholesalers like Walmart, Costco, and Target into the grocery business. In 2010, Supermarket News reported that Wal-Mart Stores, Inc. was North America's largest grocery retailer, Kroger was North America's second-largest, and Costco Wholesale Corp. was North America's third-largest. ${ }^{1}$ This has increased variety in the grocery business. Citing data from the Food Marketing Institute, Ellickson (2007:522) points out that "the number of products offered per store increased from about 14,000 in 1980 to over 30,000 by $2004 . "$

Wal-Mart Stores, Inc. again topped the Fortune 500 in 2010. Costco—categorized by Fortune as a "specialty retailer"-was ranked \#25. Also in the top 50 were big box retailers

\footnotetext{
1 “SN's Top 75 Retailers for 2010.” http://supermarketnews.com/profiles/top75/2010/index.html/, accessed December 30, 2010.
} 
Home Depot (\#29), Lowe's (\#42), and Best Buy (\#45), and general merchandisers Target (\#30) and Sears Holdings (\#48). 2010 revenues for Wal-Mart Stores, Inc. were higher than 2010 revenue for these other firms combined. ${ }^{2}$

Motivated by this trend toward nontraditional retail outlets, a growing body of research examines the effects of Walmart on a number of outcomes, including prices (Basker 2005b; Basker and Noel 2009; Volpe and Lavoie 2007; Hausman and Leibtag 2007, 2009), labor market outcomes (Basker 2005a; Hicks 2007; Neumark et al. 2008; Dube et al. 2007; Basker 2006), poverty (Goetz and Swaminathan 2006), small business activity (Sobel and Dean 2008), social capital (Goetz and Rupasingha 2006; Carden et al. 2009a), leisure activities (Carden and Courtemanche 2009), traditional values (Carden et al. 2009b), and obesity (Courtemanche and Carden 2011). ${ }^{3}$ However, to our knowledge no previous research has used nationwide data to explore the effects of other big box chains. We provide a first step toward filling this void.

Basker (2005a), Volpe and Lavoie (2007), Hausman and Leibtag (2007, 2009), and Basker and Noel (2009) present evidence that Walmart discount stores and Supercenters reduce market prices, both directly through their price advantages and indirectly through their influence on competitors. The competitive response need not be to reduce prices, however, as retail firms also compete on margins like distribution services, assortment, and convenience. In two papers on the structure of grocery retail, Ellickson $(2004,2007)$ argues that grocery stores compete by offering greater variety, which requires investments in distribution centers that increases quality by raising fixed costs, but not marginal costs (Ellickson 2004:524). Incumbents incur larger fixed costs to build better distribution networks; according to Ellickson $(2004,2007)$, this

\footnotetext{
${ }^{2}$ "Fortune 500.” http://money.cnn.com/magazines/fortune/fortune500/2010/, accessed December 30, 2010.

${ }^{3}$ Comprehensive reviews of the literature on Walmart can be found in Basker (2007), Hicks (2007), Carden et al. (2009a), and Carden and Courtemanche (2009).
} 
explains why larger markets have higher-quality products and greater selection rather than more firms. $^{4}$

We estimate the effects of Costco and Sam's Club on grocery prices using a unique dataset of warehouse club entry dates and locations matched with city-level panel data on prices of a range of items from the American Chamber of Commerce Researchers Association Cost of Living Index (ACCRA COLI). ${ }^{5}$ The ACCRA COLI does not sample warehouse clubs, so our estimates capture the competitive effects of Costco and Sam's Club on prices charged by incumbent grocers in a market. Controlling for Walmart Supercenters, product-by-year fixed effects, city fixed effects, and lagged price, a new Costco increases competitors' grocery prices by a statistically significant $1.4 \%$ in the short run and $2.7 \%$ in the long run, while the impact of a new Sam's Club is small and insignificant. The results also provide further evidence that Walmart Supercenters reduce grocery prices.

We conduct a falsification test and a wide range of robustness checks in order to increase confidence that the estimates reflect causal effects rather than spurious correlations. We also stratify by product and product type and find that Costco's effect is somewhat larger for the goods for which ACCRA's data collection process allows product quality to vary across stores. We interpret this as preliminary evidence that firms' responses to Costco entry include some competition along the quality dimension. Finally, we test for heterogeneity on the basis of market characteristics and show that Costco has the strongest effects in cities with low populations and a large number of grocery stores per capita. Our results are consistent with the findings of Basker (2005a), Volpe and Lavoie (2007), and Basker and Noel (2009) that Walmart Supercenters lower prices, Barber and Tietje's (2004) finding that incumbent firms might raise

\footnotetext{
${ }^{4}$ Ellickson $(2004,2007)$ notes that there is still a low-price, low-quality fringe in these markets.

${ }^{5}$ ACCRA is now the Council for Community and Economic Research (www.c2er.org).
} 
prices as a strategic response to new entry, and Ellickson's $(2004,2007)$ models whereby grocery stores compete on the basis of quality and improved distribution networks. Further, these results suggest that Costco might capture price-sensitive shoppers and leave incumbents to serve shoppers who are less price sensitive.

\section{THEORY AND BACKGROUND}

\section{Retail Price Responses to Competitive Pressure}

The market is a process of harmonizing buyers' and sellers' plans; under ceteris paribus conditions, these plans will coordinate fully until equilibrium is obtained and no one has an incentive to change his or her actions (cf. Hayek 1948:41-45). At issue is whether entrepreneurship upsets the process (Schumpeter 1942) or constitutes the process (Kirzner 1973). For Schumpeter (1942), the entrepreneur is a dis-equilibrator who changes the underlying pattern of preferences, technology, and resources. For Kirzner (1973), the entrepreneur is an equilibrator who adjusts the production process to the underlying pattern of preferences, technology, and resources. Regardless, entrepreneurship and competition are processes of active adjustment rather than passive observance and acquiescence to exogenously-changing conditions (Klein 2010:54-55). Boudreaux (1994) analyzes the ways in which Schumpeter and Kirzner emphasize different aspects of the adjustment process, noting that the Kirznerian entrepreneurial function and the Schumpeterian entrepreneurial function are complements, not substitutes. Boudreaux (1994: 57) discusses the complementarity specifically: "Whereas Schumpeter highlighted those activities that change the givens, Kirzner's focus is on the activities that actually establish equilibrium prices given the particular givens." ${ }^{\prime \prime}$

\footnotetext{
${ }^{6}$ See Boudreaux (1994:56ff) for a graphical discussion of the complementarity.
} 
The things we hold constant under the ceteris paribus conditions that are used to isolate and analyze pure price competition are often the very elements of the competitive process that are most important (Boudreaux 1994:53, citing Schumpeter 1942:84). Incumbents' reactions to warehouse club entry illustrate the processes of dis-equilibrating and re-equilibrating competition along the margins that make up the retail offer. In this case, we observe dis-equilibrating entry by large-scale retailers like Walmart and Costco. The price effects that we observe over the long run represent the re-equilibrating responses of incumbents who have to innovate in response to competitors' entry.

Our finding that neither Costco nor Sam's Club reduces competitors' prices - and in fact that Costco increases them - might be surprising in light of evidence on the price effects of Walmart discount stores and Supercenters. Basker (2005a), Hausman and Leibtag (2007, 2009), and Basker and Noel (2009) have shown not only that retailers like Walmart sell goods at considerable discounts, but also that incumbent retailers reduce their prices when faced with competition from new Walmart stores. Matsa (2011) finds that competitors tend to have fewer inventory shortfalls in response to Walmart's competition, and non-price margins like quality might be the most important aspects of the Costco effect.

The theoretical effect of new competitive pressure on retail prices is ambiguous because the retail offer is multi-dimensional. When consumers are deciding whether to buy something from a particular retailer, they are evaluating a bundle that includes a good, a level of service, a location, assortment and variety, a shopping ambiance, and a degree of risk regarding whether the store will have what the shopper seeks. The good is the only part of the mix that is priced explicitly. Other aspects of the retail offer are priced implicitly. 
Models of the economics of retail are summarized by Betancourt (2004). Retailers face the following inverse demand function, adapted from Betancourt (2004:23):

$$
P_{i}=f\left(Q_{i}, D_{i}, P_{i}^{\prime}, W\right)
$$

where $P$ is price, $Q$ is quantity, $D$ is a vector of distribution services, $W$ is consumer income, and $P^{\prime}$ is a vector of other prices that might affect the market for (say) bread. Price is non-increasing in $Q$ and non-decreasing in the elements of $D$ and $W$; its relationship to $P_{i}$ ' is ambiguous a priori. In a market where there are $n$ competitors, firm $i$ will face an inverse demand function in which its price is also a function of the quantities, distribution services, and prices offered by potential competitors:

$$
P_{i}=f\left(Q_{i}, D_{i}, P_{i}^{\prime}, W ; P_{j}, Q_{j}, D_{j}, P_{j}^{\prime} ; \ldots ; P_{n}, Q_{n}, D_{n}, P_{n}^{\prime}\right)
$$

More fully, every aspect of a firm's offer will change in response to competing firms' decisions regarding price, quantity, distribution services, and the prices of other goods, yielding the following general inverse demand function:

$$
P_{i}=f\left(\begin{array}{c}
Q_{i}\left(P_{j}, Q_{j}, D_{j}, P_{j}^{\prime} ; \ldots ; P_{n}, Q_{n}, D_{n}, P_{n}^{\prime}\right), D_{i}\left(P_{j}, Q_{j}, D_{j}, P_{j}^{\prime} ; \ldots ; P_{n}, Q_{n}, D_{n}, P_{n}^{\prime}\right), \\
P_{i}^{\prime}\left(P_{j}, Q_{j}, D_{j}, P_{j}^{\prime} ; \ldots ; P_{n}, Q_{n}, D_{n}, P_{n}^{\prime}\right), W ; P_{j}, Q_{j}, D_{j}, P_{j}^{\prime} ; \ldots ; P_{n}, Q_{n}, D_{n}, P_{n}^{\prime}
\end{array}\right)
$$

The direct effects of competitors' decisions on a firm's prices might be straightforward: all else equal, a firm will compete by lowering price in response to a competitor's improved service, ambiance, or other amenities. The sensitivity of the other components of the retail offer to competitors' decisions, though, means that the effect of entry on observed prices will be ambiguous a priori. Super Walmart, which specializes in low prices and low amenities, will generate a different response than will a retailer like Whole Foods Market that specializes in high amenities and selection of natural and organic products. Similarly, Costco might offer a bundle of prices and distribution services that induces incumbents to make price-increasing changes to their operations, Super Walmart might offer a bundle of prices and distribution services that 
induces incumbents to make price-reducing changes to their operations, and Sam's Club might offer a bundle or prices and distribution services that leaves incumbents' prices unchanged. Costco, for example, might capture price-sensitive consumers who are willing to drive longer distances for a less pleasant shopping experience in order to obtain deep discounts. In this case, we would expect to see prices rise among incumbent grocers as they lose shoppers who are more price-sensitive and serve shoppers who are less price-sensitive.

According to Ellickson $(2004,2007)$, large grocery chains compete on the basis of quality and variety, which requires substantial fixed investments in retail services. This is also consistent with Hollander's (1960:37) discussion of "the wheel of retailing," whereby "new types of retailing frequently start off with crude facilities, little prestige, and a reputation for cutting prices and margins. ${ }^{7}$ As they mature, they often acquire more expensive buildings, provide more elaborate services, impose higher margins, and become vulnerable to new competition." Hollander describes this as "a ratchet process" through which "merchants in any established branch of trade tend to provide increasingly elaborate services at increasingly higher margins" (Hollander 1960:38). As firms move along the wheel toward "increasingly elaborate services," they provide incentives for innovators and entrepreneurs to introduce newer retail forms. Innovators and entrepreneurs introducing new retail forms in turn put pressure on incumbents to provide higher-quality services in order to stay competitive.

\section{Price Effects of Big Box Retailers}

Hausman and Leibtag (2007) examine a basket of 20 food items and find that prices at supercenters, mass merchandisers, and club stores (which include Costco and Sam's Club) are $5 \%-48 \%$ lower than prices at conventional retailers such as supermarkets. Walmart's food prices

\footnotetext{
${ }^{7}$ We thank John Planchon for directing us to this work.
} 
are lower by 8-27\% according to data from studies discussed by Hausman and Leibtag (2009). They argue that Walmart's effect on prices is so large that the Consumer Price Index is biased upward by failing to account for its presence. Membership fee warehouses are an exercise in two-part tariff price discrimination, but entry by a warehouse club like Sam's Club or Costco also introduces a new brand of competition into the marketplace. If, as Hausman and Leibtag (2009) argue, the opportunity to shop at Walmart should be considered a new good by the Bureau of Labor Statistics, this is perhaps doubly true for warehouse clubs like Sam's Club and Costco.

Volpe and Lavoie (2007) report that Walmart Supercenters have a distinct price advantage over both stores that compete with them directly (other stores within a five-mile radius) and comparison stores with whom they do not compete directly (stores outside that fivemile radius). Using data on 54 goods collected at 18 stores in Massachusetts, Rhode Island, and Connecticut, they show that the average price of a thirty-good basket of national brand goods is $\$ 82.94$ at the comparison stores, $\$ 76.04$ at the competing stores, and \$59.38 at Walmart Supercenters. A 24 -item basket of private-label goods is $\$ 50.99$ at comparison stores, $\$ 46.73$ at competing stores, and $\$ 33.99$ at Walmart Supercenters. Also relevant for our study is their observation that competition with Walmart occurs across a variety of dimensions, with “(n)onprice strategies includ(ing) improving service, image, or variety” (Volpe and Lavoie 2007:10).

Using ACCRA COLI data from 1982-2002, Basker (2005) estimates the effect of Walmart on the market prices of ten non-food items such as shampoo, toothpaste, and laundry detergent. She finds that Walmart entry generally reduces prices by $1.5 \%-3 \%$ in the short run and about four times as much in the long run. She notes that the ACCRA data do include some 
Walmart stores, so her estimates represent weighted averages of Walmart's price advantage and its effect on competitors' prices.

The paper most closely related to ours is Basker and Noel (2009), who use 2001-2004 ACCRA COLI data to show that entry by a Walmart Supercenter drives down prices among competing grocery stores. They use a more limited range of years than Basker (2005) because for 2001-2004 they are able to determine the identity of the sampled stores, allowing them to exclude Walmart stores from the price computations and thereby isolate Walmart's effect on competitors. Pooling prices from 24 grocery items, they estimate that an additional Walmart Supercenter in a city reduce prices at incumbent retailers by $1-1.2 \%$, with the largest changes occurring among smaller and lower-end grocers.

While credible estimates of the price effects of Walmart and Walmart Supercenters are therefore beginning to emerge, little is known about the effects of other big box chains. ${ }^{8}$ Warehouse clubs, which offer steep discounts on goods purchased in bulk to customers who pay a small membership fee, represent a fundamental change in shopping technology and could plausibly have even more dramatic effects on competitors' prices than Walmart. On the other hand, incumbents could decide that warehouse clubs' price advantages are so large that competition along the price dimension is futile, leading them to compete by providing higher-end products or shopping experiences and raising prices.

\section{Sam's Club and Costco: Differences}

Warehouse clubs are important because they represent another step in a series of changes in shopping technology. The key differences between mass merchandisers like Walmart and grocery stores is that stores like Walmart carry more product categories with less variation within

\footnotetext{
${ }^{8}$ In one study, Barber and Tietje (2004) studied entry by a Home Depot and found that one of the incumbent hardware stores raised prices on some of its goods in response. This paper is discussed by Betancourt (2004:36ff).
} 
each category (Fox et al. 2004:S36). This is even truer for warehouse clubs. In contrast to conventional supermarkets and mass merchandisers, they carry a relatively limited selection of name-brand or house-brand goods (e.g. Member's Mark at Sam's Club and Kirkland's at Costco). Supermarkets tend at times to carry brands in great variety while superstores tend to carry brands in more limited varieties. Warehouse clubs are more likely to carry an even less diversified product line: they may carry only one brand of spaghetti sauce, for example. ${ }^{9}$

While all warehouse clubs share these general features, notable distinctions exist within the warehouse club category. In particular, the two leading chains - Sam's Club and Costco differ with respect to their customer base. ${ }^{10}$ Sam's Club has historically targeted small businesses, as evidenced by their former slogan "We're in Business for Small Business", while Costco has focused more heavily on individual consumers. According to their 2009 10k form, Wal-Mart's “focus for Sam's Club is to provide exceptional value on brand-name merchandise at 'members only' prices for both business and personal use” (p. 3). Costco, by contrast, "operate[s] membership warehouses based on the concept that offering our members low prices on a limited selection of nationally branded and selected private-label products in a wide range of merchandise categories will produce high sales volumes and rapid inventory turnover" (Costco 2009 10-K, p. 3). The different focuses are also evident in Walmart's 2009 annual report, which devotes a paragraph to Sam's Club's focus on supplying small businesses. ${ }^{11}$ According to the store's website, Sam's offers Advantage Membership, Advantage Plus membership (which offers access to more discounts and greater cash back rewards on the affiliated credit card), Business Membership, and Business Plus membership. According to

\footnotetext{
${ }^{9}$ Bates (1977 [2002]) offers an early discussion of the warehouse club format.

${ }^{10}$ BJ's Wholesale Club, which operates primarily on the east coast, is another important player in the warehouse club market. For reasons discussed in the data section, we do not include BJ's in our empirical analysis and therefore do not discuss it here either.

${ }^{11}$ http://walmartstores.com/sites/AnnualReport/2009/sams_club.html, accessed July 14, 2010.
} 
Costco's website, one can be a Gold Star Member, a Business Member, or an Executive

Member. Business membership and Gold Star membership both cost $\$ 50$ while Executive membership costs $\$ 100$. At Sam’s Club, Business membership costs $\$ 35$, Advantage membership costs $\$ 40$, and both of the "plus" memberships cost $\$ 100$ as of mid-2010. ${ }^{12}$ Sam's offers extended hours for business members, while Costco does not. ${ }^{13}$ Sam's Club also offers detailed services for small businesses on a dedicated website. ${ }^{14}$

Table 1 compares Costco and Sam's Club sales by category for 2009. The categories are not strictly comparable as the two stores use slightly different terminology and slightly different definitions. For Costco, for example, "Food" is the sum of their category "Food" (21\%), which is defined as "including dry and institutionally packaged foods," and their category "Fresh Food" (12\%), which is defined as “including meat, bakery, deli, and produce." Sam's Club defines their category "Food" as "including dairy, meat, bakery, deli, produce, dry, chilled, and frozen packaged foods."15 The data should be interpreted with caution, but they suggest that Sam's Club gets a much greater percentage of its sales from "Sundries," which it defines as "including snack foods, tobacco, alcoholic and nonalcoholic beverages, paper goods, laundry and home care and other consumables" and which Costco defines as "including candy, snack foods, tobacco, alcoholic and nonalcoholic beverages and cleaning and institutional supplies." Hardlines and softlines—called "hardgoods" and "softgoods" for Sam's Club—provide a greater percentage of

\footnotetext{
${ }^{12}$ Information found at https://www.samsclub.com/sams/checkout/membership/purchaseMembership.jsp and http://shop.costco.com/membership/join-costco, both accessed July 14, 2010.

${ }_{13}$ Anecdotal evidence - a conversation with a store associate at the customer service desk at Sam's Club-also supports the notion that Sam's Club caters mostly to small businesses while Costco caters mostly to families. ${ }^{14} \mathrm{http}: / /$ www3.samsclub.com/smallbusiness, accessed December 31, 2010.

15 The fact that Costco includes a separate category for "Fresh Food" suggests a different clientele. In an informal conversation between one of the authors and an employee at one of the stores, the associate said that Sam's Club serves small businesses while Costco's target customers are middle-class families. An employee of a store that competes with both Sam's Club and Costco pointed out that store design, convenience, and customer service are important elements of his firm's competitive strategy. Finally, an example is also suggestive. A friend of one of the authors once asked his six-year-old son where he wanted to go for breakfast after church. The child's reply: "Costco."
} 
Costco's sales than Sam's Club's. Costco's hardline goods “includ[e] major appliances, electronics, health and beauty aids, hardware, office supplies, garden and patio, sporting goods, furniture, and automotive supplies" while Sam's Club's hardgoods "includ[e] home improvement, electronics, office supplies, outdoor living, grills, gardening, and furniture." Costco's softlines “includ[e] apparel, domestics, jewelry, housewares, media, home furnishings, cameras, and small appliances" while Sam's Club's "softgoods" includ[e] apparel, jewelry, housewares, mattresses, and small appliances."

\section{DATA}

Following Basker (2005b) and Basker and Noel (2009), we use price data from the Council for Community and Economic Research's (C2ER) ACCRA COLI. Through local chambers of commerce, the ACCRA COLI computes quarterly market prices for a wide range of grocery, energy, transportation, housing, health care, and other items by surveying retailers in between 274 and 334 small geographic areas. For simplicity, we refer to each area as a "city" throughout the rest of the paper, although some are actually multiple cities (i.e. BarreMontpelier, VT) or entire counties. As a robustness check we later show that the results are not sensitive to dropping the multiple cities and counties from the sample.

We examine the effects of Costco, Sam's Club, and Walmart Supercenter on the prices of the 23 grocery items the ACCRA COLI reported consistently during our sample period. These products, which we describe in Table 2, span a variety of different categories: starches, fruits and vegetables, meats, beverages, additives, and non-food items. We also conduct a falsification 
exercise that tests for "effects" of these stores on the prices of 9 non-grocery items described in Table 3 that big box retailers do not typically sell. ${ }^{16}$

Whether warehouse clubs and Supercenters are among the stores surveyed in the ACCRA COLI is critical to the interpretation of the results. As noted by Basker and Noel (2009:982), the sampling instructions specifically excluded membership clubs such as Costco and Sam's Club, so any estimated effect of these stores represents a response by competing grocers. The instructions also discouraged the inclusion of Walmart Supercenters, saying that discount retailers should not be sampled "unless upper-income professionals and executives really shop there" (ACCRA 2000:1.3). However, Basker and Noel (2009:982) report that 14\% of grocery prices were nonetheless collected at Supercenters. Our estimated effect of Supercenters therefore represents a weighted average of their price advantage and their effect on competitors. Both because interpretation of the results is less clear for Supercenters and because prior research has already estimated Supercenters' competitive effects, we emphasize the results for Costco and Sam's Club in this paper. Including Supercenters as a control variable is still critical, however, since Sam's Clubs and Walmarts are often located together.

We merge the ACCRA COLI price data with a newly-constructed database of big box retailer and distribution center locations. Costco, Sam's Club, and BJ's Wholesale Club data through May of 2003 were collected by Austan Goolsbee and Chad Syverson and generously shared by Chad Syverson. We updated these warehouse club data through the end of 2008 using the store locators on Costco.com and bjs.com, along with Sam's Club opening dates since 2003 provided by Walmart Stores, Inc. We assembled Costco, Sam's Club, and BJ's Wholesale Club

\footnotetext{
${ }^{16}$ Note that some warehouse clubs have tire and auto centers while Walmart Supercenters increasingly have hair salons, so the falsification tests are perhaps not perfect for these particular items. Excluding them does not, however, affect our results. Note also that we do not use the energy and housing prices in the falsification analysis as they are less obviously comparable to grocery prices than the prices for the other non-grocery items. Including them also does not affect the results.
} 
distribution center locations and opening years by first searching Google Maps to find the locations, and then contacting the distribution centers and local chambers of commerce to determine entry years. Though our database therefore contains all three leading warehouse club chains, we do not use the BJ's Wholesale Club information in this paper since only one of the cities in our matched sample experienced BJ's Wholesale Club entry during the sample period. Walmart Supercenter, discount store, distribution center, and food distribution center entry dates and locations through January of 2006 were graciously provided online by Thomas Holmes and used in Holmes (2008). ${ }^{17}$ We updated these Walmart data through the end of 2007 using the store locators on Walmart.com along with press releases containing store and distribution center opening dates.

We also include other city- and county-level characteristics as controls in some regressions. City population and land area from 2000 and median household income from 1999 come from the U.S. Census Bureau, accessed via Statistical Warehouse. The number of grocery stores and warehouse clubs or supercenters besides our stores of interest in each county (comparable city-level data are not available) are taken from the 1992, 1997, and 2002 Censuses of Retail Trade and imputed for the remaining years through linear interpolations and extrapolations.

We construct our sample by matching the annual store, distribution center, and control variables to fourth quarter ACCRA prices from 1994 to 2006 . We use only one quarter per year as for some stores and distribution centers we know the year but not the month of entry. Given this limitation, the fourth quarter is the most natural choice in order to maximize the probability that new stores in a particular year open before the prices are recorded. As a robustness check we later show the results are similar if we instead match first quarter prices to store locations

\footnotetext{
${ }^{17}$ See http://www.econ.umn.edu/ holmes/data/WalMart/index.html.
} 
from the end of the previous year. We exclude years before 1994 because in 1993 Costco merged with Price Club while Walmart acquired PACE Wholesale Club; a large number of Costcos and Sam's Clubs therefore opened in 1993 and 1994 that were not actually new warehouse clubs. The ACCRA COLI cities varied somewhat over time; we include the 289 cities surveyed in over half of the 13 years. Our sample consists of 70,604 product-city-yearlevel observations for the main analysis and 27,657 for the falsification exercise.

Tables 2-4 present the descriptive statistics for the variables used in the empirical analysis. The sample mean grocery item price is $\$ 2.37$, with average prices for the individual products ranging from $\$ 0.59$ per pound of bananas to $\$ 7.99$ per pound of T-bone steak. The average sample city has 0.2 Costcos, 0.7 Sam's Clubs, and 0.7 Walmart Supercenters and a population of about 200,000 .

\section{EMPIRICAL ANALYSIS}

Our empirical analysis proceeds as follows. We begin by estimating the average effects of Costcos, Sam's Clubs, and Supercenters on the price of grocery items. Motivated by approaches used in the literature, we develop a baseline fixed effects model that we validate through a falsification test. We then evaluate the sensitivity of our baseline results through a wide range of robustness checks. Next, we examine the timing of the effect by including leads and lags, the former of which provides an additional test for endogeneity bias. Finally, we explore the possibility of heterogeneity on the bases of product and market characteristics.

\section{Baseline Model and Falsification Test}

Basker and Noel (2009) estimate the effect of Walmart Supercenter entry on competitors' grocery prices using ACCRA COLI data from the third quarters of 2001-2004. Their preferred specification regresses the natural log of price on the number of Walmart Supercenters in the city 
along with city and product-by-year fixed effects. They also estimate cross-sectional, long difference, and (in their appendix) instrumental variables models, but they favor the fixed effects specification based on its utilization of all available information and its passage of a falsification test. Our baseline model adopts Basker and Noel's (2009) fixed effects approach but adds Costco, Sam's Club, and the annual lag of the log of price. We include lagged price because Basker (2005b) documented the stickiness of price shocks in her earlier analysis of the effect of Walmart on ACCRA COLI prices; presumably Basker and Noel (2009) did not also include lagged price because of the short duration of their panel. Our regression equation is

$$
\begin{aligned}
p_{i c t}= & \beta_{0}+\beta_{1} \operatorname{costco}_{c t}+\beta_{2} \text { sams }_{c t}+\beta_{3} s w m_{c t}+\beta_{4} p_{i c, t-1}+\sum_{c} \alpha_{c} c{ } i t y_{c} \\
& +\sum_{i t} \theta_{i t} \text { product }_{i} \tau_{t}+\varepsilon_{i c t} .
\end{aligned}
$$

where $p_{i c t}$ is the price (in 2006 dollars) of product $i$ in city $c$ in year $t$; $\operatorname{costco}_{c t}, \operatorname{sams}_{c t}$, and $s w m_{c t}$ indicate the number of Costcos, Sam's Clubs, and Walmart Supercenters in city c in year $t ; p_{i c, t-1}$ is the lagged product price; and the summation terms reflect city fixed effects and product-by-year fixed effects. Standard errors are heteroskedasticity-robust and adjusted for clustering at the city level. ${ }^{18}$

The dynamic model (4) allows for the estimation of both short- and long-run effects. The short run effects of Costcos, Sam's Clubs, and Supercenters are given by $\beta_{1}, \beta_{2}$, and $\beta_{3}$. Computing long-run effects requires considering that a store that entered prior to the current year impacts contemporaneous price not only through contemporaneous number of stores but also

\footnotetext{
${ }^{18}$ OLS coefficient estimators in models with lagged dependent variables can be inconsistent if the errors are serially correlated (Keele and Kelly 2006). We tested for serial correlation by compressing the data into a two-dimensional panel by computing average product prices in each city in each year, running an analogous regression to equation (4), and then performing the Arrelano-Bond test using the Stata module "abar" (Roodman 2004). The test found only weak evidence of first-order autocorrelation (significant at only the $5 \%$ level despite the large sample size). When the extent of the autocorrelation is small, the bias is negligible in large samples (Keele and Kelly 2006). We therefore estimate the model using OLS, and later conduct robustness checks to rule out the possibility that serial correlation is driving our conclusions.
} 
through lagged price. If, for instance, a new Costco enters, the immediate effect on price is $\beta_{1}$, the additional effect the following year is $\beta_{1} \beta_{4}$, the additional effect the year after is $\beta_{1} \beta_{4}{ }^{2}$, then $\beta_{1} \beta_{4}{ }^{3}$, and so on. The total long-run effect of Costco is therefore given by the following geometric series:

$$
\sum_{t=0}^{\infty} \beta_{1} \beta_{4}{ }^{t}=\frac{\beta_{1}}{\left(1-\beta_{4}\right)}
$$

The long-run effects of Sam's Club and Walmart Supercenter can also be computed by replacing $\beta_{1}$ with $\beta_{2}$ and $\beta_{3}{ }^{19}$

The key identifying assumption in regression equation (4) is that changes over time in unobservable city-level characteristics affecting prices are uncorrelated with changes in Costco, Sam's Club, and Supercenter presence. This assumption would be violated if, for instance, a positive demand shock both increases a city's grocery prices and makes it more attractive to big box retailers. Basker and Noel (2009) provide evidence to support the strict exogeneity assumption in fixed effects regressions with Supercenters from 2001-2004, but it is not clear that this generalizes to regressions with three stores and a longer time period. We therefore conduct a falsification test where we re-estimate equation (4) using non-grocery instead of grocery prices as the dependent variable. Since Costcos, Sam's Clubs, and Supercenters generally do not sell substitutes for the non-grocery items, a finding that any of these stores "affect" the prices of nongrocery items could be attributed to endogeneity bias, thereby calling into question the ability of the model to reveal causal effects on grocery prices.

We report the results for the baseline regression and falsification test in Tables 5. A new Costco is associated with a statistically significant increase in grocery prices of $1.4 \%$ in the short

\footnotetext{
${ }^{19}$ See Basker (2005b) for further discussion of the derivation of long-run effects in this context.
} 
run and $2.7 \%$ in the long run. The effect of Sam's Club, however, is small and insignificant. Walmart Supercenters reduce prices by a statistically significant $0.9 \%$ in the short run and $1.7 \%$ in the long run. Our Supercenter estimates are in line with those obtained by Basker and Noel (2009). We take this as evidence that, even though our ACCRA COLI data do not allow for the exclusion of Walmarts from the stores used to compute market prices, our estimates for Supercenters mostly reflect a competitive effect rather than Walmart's price advantage. Importantly, the falsification test estimates small and insignificant effects of all three stores, providing preliminary evidence to support the baseline model. We next further test the validity of this specification by subjecting it to a number of robustness checks.

\section{Robustness Checks}

In this section we evaluate the sensitivity of the results from our preferred regression. Our robustness checks fall into five categories: additional control variables, alternate specifications for the store variables, other methods of sample construction, longer lags of price, and instrumental variables.

In Panel A of Table 6 we report the results from re-estimating equation (4) including four different sets of control variables. First, we add interactions of each of the year fixed effects with city population. This addresses potential endogeneity bias from highly populated cities both experiencing differential price shocks and being more (or less) likely to attract big box retailers. Next, we add interactions of the year fixed effects with median city income to capture differential trends in price between high and low income areas. Third, we control for the countylevel numbers of grocery stores and warehouse clubs or supercenters (besides our stores of interest) to help verify that our estimates reflect the effects of Costco, Sam's Club, and Walmart 
rather than overall retail structure. ${ }^{20}$ This also addresses the possibility that the effects may be partly due to grocers going out of business when faced with competition from big box retailers. Finally, we consider a more general approach to modeling differential trends by including cityspecific time trends, created by interacting each of the city fixed effects with linear year. In all four regressions, the estimated short- and long-run effects for each of the three stores remain virtually identical.

Panel B presents results from various alternative specifications for the Costco, Sam's Club, and Supercenter variables. These include the number of stores per 100,000 residents or 100 square miles in the city, binary variables reflecting the presence of at least one store in the city, and the number of stores in the county rather than the city. The first three reflect other measures used in the Walmart literature, while the fourth could potentially alter the results to the extent that big box retailers in outlying parts of a county draw customers away from grocery stores within the city limits. As shown in the summary statistics in Table 4, the distributions for the store variables vary considerably depending on which specification is used, so the coefficient estimates are not comparable to those from the baseline model. However, we observe the same general pattern regarding signs and significance. Costcos consistently increase grocery prices, while Walmart Supercenters consistently reduce them. The effect of Sam's Club remains small and statistically significant in the first three rows of Panel B. Using the county-level market definition, Sam's Clubs appear at first to increase prices - however, as we show in the next row this association disappears if county-specific time trends are added.

\footnotetext{
${ }^{20}$ In unreported regressions, we also added the number of Walmart discount stores to the model. Walmart discount stores do not contain a full grocery section but do sell a limited range of (typically processed) foods, so it is conceivable that they could affect market prices for some grocery items. We found it difficult to jointly identify the effects of discount stores and Walmart Supercenters, as the vast majority of changes in discount store presence in our sample reflected a conversion from a discount store to a Supercenter rather than a new discount store. We therefore do not report the results, though the estimates for Costco and Sam's Club remain similar.
} 
In Panel C, we show that the results are also robust to different sample construction rules. Recall that cities move in and out of the ACCRA COLI sample over time, and that we use an unbalanced panel of the cities included in over half of the sample years. In the first row, we restrict the sample to those cities present in every year. This eliminates almost $2 / 3$ of the sample and therefore increases the standard errors, but the coefficient estimates remain similar. The next two robustness checks drop the multiple cities and counties from the sample and use the first quarter of the following year (1995-2007) rather than the fourth quarter of the current year (1994-2006). Finally, we consider a more drastic change to the sample: instead of pooling the products, we compress the available information into one observation per city per year by computing both simple and weighted (by the shares given in the ACCRA COLI) average prices for the basket of grocery items. In all cases, the point estimates remain virtually identical.

The first three regressions reported in Panel D replace the lagged grocery price variable with longer lags of 2, 3, and 4 years and show that the results remain similar. These robustness checks address the concerns that serial correlation in the error term or measurement error in the price data may bias the coefficient estimator for lagged price, and that some of the bias could spill over into the coefficient estimators for the store variables. The correlation between unobservables that affect contemporaneous and lagged price should weaken with longer lags, so the fact that the results are not sensitive to lag length helps to alleviate this concern. The fourth row of Panel D drops lagged price completely. In this specification, the estimated short- and long-run effects are constrained to be the same and are represented by the coefficient estimates. Dropping lagged price does not affect the conclusions reached.

We close this section by considering an entirely different identification strategy. Instead of attempting to control for the sources of endogeneity bias through city fixed effects, we attempt 
to purge the bias by using distance from the nearest Costco, Sam's Club, and Walmart food distribution centers (and their squares) as instruments for the three endogenous variables. ${ }^{21}$ Distance to the nearest distribution center affects operating costs and therefore provides a source of variation in a city's store presence that is potentially uncorrelated with demand-side characteristics influencing price levels. A concern with this approach, however, is that distribution center and store presence may be jointly determined - a corporation may decide to open a series of stores in a potentially profitable area along with a distribution center to service those stores. Another limitation is that there is not enough variation over time in cities' distances from distribution centers for the IV estimates to be meaningfully precise in models with city fixed effects; we therefore do not include fixed effects in the reported IV regressions. Because of these limitations, we prefer to use the IV analysis as a supplemental robustness check rather than as our main approach.

Panel E reports the IV results, with the F statistics from tests of the joint significance of the instruments in the first-stage regressions in brackets. The second row adds population, population density, and median income as controls in an attempt to compensate somewhat for the lack of city fixed effects. In both regressions, the usual pattern emerges: Costcos significantly increase grocery prices, Supercenters significantly decrease them, and Sam's Clubs have no statistically detectable effect. The estimates for Costcos and Supercenters are larger than in the baseline regressions, though adding the control variables attenuates them slightly. The IV estimators do not perform as well as the baseline fixed effects estimators in falsification tests, however, so we consider the fixed effects results more reliable. Specifically, if we estimate the IV model with controls using non-grocery prices as the dependent variable, Costco's short-run

\footnotetext{
${ }^{21}$ We considered a number of functional forms and the quadratic specification maximized the first-stage F statistics. The conclusions reached are generally not sensitive to the functional form used.
} 
"effect" is a significant $1.5 \%$. The difference between Costco's short-run impacts on grocery and non-grocery prices - which is perhaps better reflective of its true causal effect - is therefore $1.9 \%$, well within the $95 \%$ confidence interval from our preferred fixed effects specification.

\section{Timing}

We next examine timing by adding leads and lags of the three stores. A finding that lagged Costco, Sam's Club, and Supercenter presence impact grocery prices conditional on current presence of these stores and lagged grocery prices would provide evidence that the timing of the effect is less smooth than the relationship given by equation (5). If the leads of Costco, Sam's Club, and Supercenters impact grocery prices and cause the estimated effects of contemporaneous stores to change, this would suggest the associations estimated in the preceding sections do not reflect causal effects - price levels are likely determining store entry instead of the other way around.

Table 7 presents results from regressions including one, two, or three year lags of each of the three stores, while Table 8 includes one, two, or three year leads. In unreported regressions we verified the conclusions reached are similar with longer lags or leads or with lags and leads included together. We find no evidence that the results from the preceding sections either misspecify the timing of the effect or reflect reverse causality. The lags for Costco, Sam's Club, and Supercenters are statistically insignificant in all cases and including them has little effect on the coefficient estimates for contemporaneous stores. The leads of Costco presence are insignificant and make virtually no difference in the estimate for current Costco presence. The leads for Sam's Clubs are significant in two regressions, but in all cases the conclusion of a small and statistically insignificant association between contemporaneous Sam's Clubs and grocery prices persists. Future Supercenters are weakly significant in one of the three regressions and 
insignificant in the other two, while in all three the estimated effect of current Supercenters remains similar.

\section{Heterogeneity by Product}

All regressions to this point have assumed the impacts of Costcos, Sam's Clubs, and Supercenters are the same across different products and markets. We relax this assumption in the final two sections of the empirical analysis, by examining first whether the effects are different for different products and then whether they depend on the size and retail landscape of the market.

We begin by stratifying the sample into product categories. First we split the sample into six categories representing starches, fruits/vegetables, meats, drinks, food additives, and nonfood items, as classified in Table 2. We next divide the sample into products for which the ACCRA COLI specifies the brand to be sampled (cereal, peas, peaches, sausage, tuna, coffee, soft drink, shortening, parmesan cheese, margarine, tissue, and dishwasher detergent) and those for which it does not (bread, lettuce, bananas, potatoes, corn, steak, beef, chicken, eggs, milk, and sugar). This categorization could potentially help explain the finding that competitors compete with Costco by raising prices instead of lowering them: if grocery stores respond to Costco entry by offering higher quality products, the price increase should be stronger among products for which the brand is not specified and therefore quality is not fixed.

Table 9 presents the results. In all eight categories, Costco increases prices, Supercenters decrease prices, and Sam's Club has no statistically detectable effect. There are, however, some important differences in the magnitudes. Costco's effect is strongest for fruits/vegetables, meats, and drinks, while Supercenters' effects are strongest for starches and fruits/vegetables. Costco leads to slightly greater price increases for items where the brand is not specified, although a 
positive effect remains even when the brand is specified. These results suggest that competition along the product quality dimension explains some but far from all of Costco's effect.

Table 10 stratifies on a finer level and presents regression results for each of the products separately. Though these estimates are relatively imprecise because of the small sample size, some interesting findings emerge. Costco's largest effect is on lettuce - an item where quality is especially variable - and it is also significant in the regressions for peas, corn, beef, eggs, tuna, coffee, soft drinks, milk, sugar, parmesan, and detergent. Though Sam's Club is insignificant for most products, consistent with the pooled results, it does lead to large and significant increases in the prices of potatoes and beef and a significant decrease in the price of shortening. Supercenters are statistically significant in every regression but lead to the largest price reductions ( $2 \%$ or more in the short run) for bread, potatoes, and corn.

\section{Heterogeneity by Market Characteristics}

We close our analysis by examining if the effects of new Costcos, Sam's Clubs, and Supercenters differ depending on how many of them are already in the city, the city's population, or the number of grocery stores in the county per 100,000 residents. The competitive effect of Costco entry, for instance, may weaken with the number of Costcos already in the market if the new store steals business from existing Costcos as well as competing grocery stores. Additional warehouse clubs or Supercenters might also exert less competitive pressure in large cities where they represent a smaller shock to the market. Finally, big box retailers could have either stronger or weaker competitive effects in cities with high grocery store densities. On one hand, grocery stores in underserved areas may not need to make significant changes after warehouse clubs or Supercenters enter in order to continue earning comfortable margins. In this case, the competitive effect would increase with grocery store density. Alternatively, in fiercely 
competitive markets grocers may already be doing everything they can to differentiate products and target particular types of consumers, in which case the competitive effect would decrease with grocery store density.

We test for nonlinearity in the effects of Costcos, Sam's Clubs, and Supercenters by reestimating our baseline regression (4) adding the squares of the three stores. In Table 11 we use these estimates to predict the effects of the first, second, third, and fourth stores to enter the average city. (We stop at four as that is the maximum number of Costcos in our sample.) We also report the coefficient estimates in the table notes. Costcos have a relatively constant effect across the distribution, while the price reductions from Supercenters become weaker with each store. The first Sam's Club to enter a city leads to a small and marginally significant increase in prices, with further stores having no statistically detectable effect.

We test for heterogeneity on the basis of population by adding interactions of each store with city population to equation (4) and obtaining new estimates. Based on these estimates, we plot in Figures 1-3 the short- and long-run effects of Costcos, Sam's Clubs, and Supercenters on prices across the population distribution (up to approximately the $95^{\text {th }}$ percentile of $1,000,000$ ). On each figure, the thick solid line represents the estimated short-run effect and the thin solid lines represent the upper and lower bounds of its $95 \%$ confidence interval. Similarly, the thick dashed line shows the estimated long-run effect while the thin dashed lines give the upper and lower bounds of its $95 \%$ confidence interval. Figure 1 shows that Costco increases competitors' prices most sharply in less populated areas. In the smallest cities Costco increases prices by about $1.5 \%$ in the short run and $2.8 \%$ in the long run. This effect gradually diminishes as population increases, eventually becoming statistically insignificant at a population of about 350,000. In Figure 2, the impact of Sam's Club appears to slightly rise across the population 
distribution, but at no point is either the short- or long-run effect statistically different from zero. Figure 3 shows that competitors in the smallest cities reduce prices by $1.3 \%$ in the short run and $2.5 \%$ in the long run in response to Supercenter entry. The effect diminishes as city population increases but remains significant throughout most of the distribution.

Finally, we examine heterogeneity on the basis of grocery store density by adding grocery stores per 100,000 residents as well as its interaction with each of the three store variables to regression equation (4). We display the results (up to the $95^{\text {th }}$ percentile of 130 grocery stores per 100,000 residents) in Figures 4-6. Figure 4 shows that grocers increase prices more dramatically when Costco enters markets that are already saturated with grocery stores. The short and long run effects both become significant at about 28 grocery stores and level off at $1.8 \%$ and $3.4 \%$, respectively, at over 100 grocery stores. The impact of Sam's Club also increases with grocery store density, as shown in Figure 5, but is never significant in either the short or long run. Figure 6 shows that Supercenters' competitive effects also strengthen in more saturated markets, becoming significant at just over 20 grocery stores and eventually reaching a reduction of $1.4 \%$ in the short run and $2.7 \%$ in the long run.

\section{CONCLUSION}

Research by Basker and Noel (2009) has shown that competing grocers lower prices in response to competition from Walmart Supercenters. We provide evidence of very different responses to competition from warehouse clubs. Using a panel of cities from the ACCRA COLI and a dynamic fixed effects model, we find that Costco entry actually results in higher prices among incumbent grocers, while competition from Sam's Club has no statistically detectable effect. We conducted a variety of tests to increase our confidence that these relationships are causal, including a falsification test with non-grocery items; the addition of control variables, 
city-specific time trends, and leads of store presence; and the consideration of an instrumental variables strategy. We also examined heterogeneity on the bases of product type, order of store entry, and market population and grocery store density. Costco's effect is strongest for items for which the brand is not specified, and in sparsely populated cities with competitive grocery markets.

Our results are consistent with work by Ellickson $(2004,2007)$ showing that firms compete on the basis of quality. They also illustrate how firms' entrepreneurial and managerial decisions are multi-dimensional. Grocery stores may elect not to compete with deep-discount membership warehouses on the price dimension, instead focusing on the less price-sensitive consumers and providing a higher quality shopping experience, higher-end products, or greater convenience.

More broadly, our work shows that not all big box chains are created equal. The big box retail literature has focused almost exclusively on Walmart, examining its effects on a wide range of outcomes including prices, labor market outcomes, small business activity, time use, obesity, and social and cultural indicators. Our finding that Costco and Sam's Club have very different effects on competitors' prices than Walmart Supercenters point to the need for future research to look beyond Walmart when examining how the proliferation of big box retailers in recent decades has impacted communities. 


\section{REFERENCES}

American Chamber of Commerce Research Association (2000). ACCRA Cost of Living Index Manual.

Barber, Clifford and Brian Tietje (2004). “A Distribution Services Approach for Developing Effective Competitive Strategies Against 'Big Box' Retailers,” Journal of Retailing and Consumer Services, 11: 98-107.

Basker, Emek (2005a). “Job Creation or Destruction? Labor-Market Effects of Wal-Mart Expansion," Review of Economics and Statistics, 87: 174-183.

Basker, Emek (2005b). "Selling a Cheaper Mousetrap: Wal-Mart's Effect on Retail Prices," Journal of Urban Economics, 58: 203-229.

Basker, Emek (2006). "When Good Instruments Go Bad: A Reply to Neumark, Zhang, and Ciccarella," University of Missouri Department of Economics Working Paper 07-06.

Basker, Emek and Michael Noel (2009). “The Evolving Food Chain: Competitive Effects of Wal-Mart's Entry into the Supermarket Industry." Journal of Economics and Management Strategy, 18: 977-1009.

Bates, Albert (1977). "Warehouse Retailing: A Revolutionary Force in Distribution?" California Management Review, 20: 74-80. Reprinted in Anne Findlay and Leigh Sparks, eds. (2002), Retailing: Critical Concepts, v. III: Retail Practices and Operations. London: Routledge, pp. 3-13.

Betancourt, Roger (2004). The Economics of Retailing and Distribution. Northampton, MA: Edward Elgar Publishing, Inc.

Boudreaux, Donald (1994). "Schumpeter and Kirzner on Competition and Equilibrium," in Peter Boettke and David Prychitko, eds. The Market Process: Essays in Contemporary 


\section{Austrian Economics. Edward Elgar.}

Carden, Art and Charles Courtemanche (2009). "Wal-Mart, Leisure, and Culture," Contemporary Economic Policy, 27: 450-461.

Carden, Art, Charles Courtemanche and Jeremy Meiners (2009a). "Does Wal-Mart Reduce Social Capital?" Public Choice, 138: 109-136.

Carden, Art, Charles Courtemanche, and Jeremy Meiners (2009b). "Painting the Town Red? Wal-Mart and Values," Business and Politics, 11: Article 5.

Courtemanche, Charles and Art Carden (2011). "Supersizing Supercenters? The Impact of Walmart Supercenters on Body Mass Index and Obesity,” Journal of Urban Economics, 69(2): 165-181.

Dube, Arindrajit., T. William Lester and Barry Eidlin (2007). "Firm Entry and Wages: Impact of Wal-Mart Growth on Earnings throughout the Retail Sector," Institute of Industrial Relations Working Paper No. iirwps-126-05.

Ellickson, Paul (2006). "Quality Competition in Retailing: A Structural Analysis," International Journal of Industrial Organization, 24(3): 521-540.

Ellickson, Paul (2007). “Does Sutton Apply to Supermarkets?” RAND Journal of Economics, 38(1): 43-59.

Fox, Edward, Alan Montgomery and Leonard Lodish (2004). “Consumer Shopping and Spending Across Retail Formats," Journal of Business, 77: S25-S60.

Goetz, Stephan and Anil Rupasingha (2006). "Wal-Mart and Social Capital," American Journal of Agricultural Economics, 88: 1304-1310

Goetz, Stephan and Hema Swaminathan (2006). "Wal-Mart and County-Wide Poverty,” Social Science Quarterly, 87: 211-226. 
Hicks, Michael (2007). "Job Turnover and Wages in the Retail Sector: The Influence of Walmart," Journal of Private Enterprise, 22: 137-159.

Harper, David (2003). Foundations of Entrepreneurship and Economic Development. London: Routledge.

Hausman, Jerry and Ephraim Leibtag (2007). “Consumer Benefits from Increased Competition in Shopping Outlets: Measuring the Effect of Wal-Mart," Journal of Applied Econometrics, 22: $1157-1177$.

Hausman, Jerry and Ephraim Leibtag (2009). "CPI Bias from Supercenters: Does the BLS Know that Wal-Mart Exists?” In W. Erwin Diewert and John S. Greenlees, and Charles R. Hulten, eds. Price Index Concepts and Measurement. Pp. 203-231. Chicago: University of Chicago Press and NBER.

Hayek, Friedrich (1848). Individualism and Economic Order. Chicago: University of Chicago Press.

Hollander, Stanley (1960). “The Wheel of Retailing.” Journal of Marketing, 25: 37-42.

Keele, Luke and Nathan Kelly (2006). "Dynamic Models for Dynamic Theories: The Ins and Outs of Lagged Dependent Variable Models.” Political Analysis, 14(2): 186-205.

Kirzner, Israel (1973). Competition and Entrepreneurship. Chicago: University of Chicago Press.

Klein, Peter (2010). The Capitalist and the Entrepreneur: Essays on Organizations and Markets. Auburn, AL: Ludwig von Mises Institute.

Matsa, David A. 2011. Competition and Product Quality in the Supermarket Industry. Quarterly Journal of Economics 126: 1539-1591.

Neumark, David, Junfu Zhang, and Stephen Ciccarella (2008). “The Effects of Wal-Mart on 
Local Labor Markets," Journal of Urban Economics, 63: 405-430.

Roodman, David (2004). “ABAR: Stata Module to Perform Arellano-Bond Test for Autocorrelation.” Boston College Department of Economics Statistical Software Components, Number S437501.

Schumpeter, Joseph (1950). Capitalism, Socialism, and Democracy. New York: Harper \& Row. Sobel, Russell and Andrea Dean (2008). "Has Wal-Mart Buried Mom and Pop? The Impact of Wal-Mart on Self Employment and Small Establishments in the United States," Economic Inquiry, 46: 676-695.

Volpe III, Richard and Nathalie Lavoie (2007). “The Impact of Wal-Mart Supercenters on Grocery Prices in New England," Review of Agricultural Economics, 30: 4-26. 
Table 1 - Costco and Sam's Club Sales By Category, 2009

\begin{tabular}{lcc}
\hline \hline & Costco & Sam's Club \\
\hline Sundries & $23 \%$ & $37 \%$ \\
Hardlines & $19 \%$ & $16 \%$ \\
Softlines & $10 \%$ & $5 \%$ \\
Food & $33 \%$ & $30 \%$ \\
Services/Anciliary & $15 \%$ & $12 \%$ \\
\hline
\end{tabular}

Sources: Wal-Mart Stores 2009 10-K, p. 10; Costco 2009 Annual Report, p. 9.

Notes: Reports offer slightly different definitions of categories and use slightly different terminology. Costco food sales is the sum of "food" and "fresh food" percentages. 
Table 2 - Grocery Item Prices (in 2006 dollars)

\begin{tabular}{|c|c|c|c|}
\hline Category & Variable & Description & Mean (Std. Dev.) \\
\hline \multicolumn{3}{|c|}{ All Items Pooled } & $2.371(1.748)$ \\
\hline \multirow{2}{*}{ Starches } & Bread & Per oz, white bread & $1.130(0.230)$ \\
\hline & Cereal & 18 oz box of corn flakes; Kellogg's or Post & $3.162(0.540)$ \\
\hline \multirow{6}{*}{$\begin{array}{l}\text { Fruits and } \\
\text { Vegetables }\end{array}$} & Lettuce & Head of iceberg & $1.283(0.222)$ \\
\hline & Bananas & Per lb & $0.593(0.111)$ \\
\hline & Potatoes & $10 \mathrm{lb} \mathrm{sack}$ & $3.386(0.910)$ \\
\hline & Peas & 15 oz can, sweet; Del Monte or Green Giant & $0.858(0.148)$ \\
\hline & Peaches & $\begin{array}{l}29 \text { oz halves or slices; Hunts, Del Monte, or } \\
\text { Libby's }\end{array}$ & $1.957(0.220)$ \\
\hline & Corn & $16 \mathrm{oz}$ whole kernel frozen & $1.326(0.238)$ \\
\hline \multirow{6}{*}{ Meats } & Steak & Per lb, t-bone & $7.986(1.284)$ \\
\hline & Beef & Per lb, ground & $2.060(0.475)$ \\
\hline & Chicken & Per $\mathrm{lb}$, whole uncut & $1.164(0.204)$ \\
\hline & Sausage & 1 lb. package; Jimmy Dean or Owen & $3.829(0.697)$ \\
\hline & Eggs & Dozen large, grade A or AA & $1.196(0.305)$ \\
\hline & Tuna & $\begin{array}{l}6 \text { oz chunk of light tuna; Starkist or Chicken of } \\
\text { the Sea }\end{array}$ & $0.859(0.166)$ \\
\hline \multirow{3}{*}{ Beverages } & Coffee & $\begin{array}{l}11.5 \mathrm{oz} \text { can; Maxwell House, Hills Brothers, or } \\
\text { Folgers }\end{array}$ & $3.588(0.840)$ \\
\hline & Soft Drink & 2 liter bottle; Coca Cola & $1.437(0.214)$ \\
\hline & Milk & Half-gallon, whole & $2.068(0.259)$ \\
\hline \multirow{4}{*}{ Additives } & Sugar & $4 \mathrm{lb}$ cane or beat & $1.940(0.253)$ \\
\hline & Shortening & 3 lb can; Crisco & $3.691(0.426)$ \\
\hline & Parmesan & $8 \mathrm{oz}$ canister of grated parmesan cheese; Kraft & $4.346(0.675)$ \\
\hline & Margarine & $1 \mathrm{lb}$ sticks, Blue Bonnet or Parkay & $0.913(0.207)$ \\
\hline \multirow{2}{*}{ Non-Foods } & Tissue & Box of $175 ;$ Kleenex & $1.607(0.225)$ \\
\hline & Detergent & $75 \mathrm{oz}$ dishwashing powder; Cascade & $4.161(0.808)$ \\
\hline
\end{tabular}


Table 3 - Non-Grocery Item Prices (in 2006 dollars)

\begin{tabular}{llc}
\hline \hline Variable & Description & Mean (Std. Dev.) \\
\hline $\begin{array}{l}\text { All Items Pooled } \\
\text { Phone }\end{array}$ & \multicolumn{1}{c}{$\begin{array}{c}\text { Private residential line, basic monthly rate, fees and taxes } \\
\text { Tire Balance }\end{array}$} & $26.573(4.742)$ \\
& $\begin{array}{l}\text { Average price to computer or spin balance, one front } \\
\text { wheel }\end{array}$ & $9.450(1.414)$ \\
Haircut & Men's barber shop haircut, no styling & $11.880(2.029)$ \\
Salon & Woman's shampoo, trim, and blow dry & $29.137(6.281)$ \\
Dry Cleaning & Man's two-piece suit & $9.402(1.362)$ \\
Washer & Home service call, clothes washing machine; minimum & $51.256(8.957)$ \\
Newspaper & labor charge, excluding parts & \\
Daily and Sunday home delivery, large-city newspaper, & $16.191(3.712)$ \\
Movie & monthly rate & \\
Bowling & First-run, indoor, evening, no discount & $8.110(0.870)$ \\
\hline
\end{tabular}


Table 4 - Store, Distribution Center, and Control Variables

\begin{tabular}{llc}
\hline Variable & Description & Mean (Std. Dev.) \\
\hline Costcos & Number of Costcos in the city & $0.183(0.509)$ \\
& Costcos per 100,000 residents in the city & $0.127(0.557)$ \\
& Costcos per 100 square miles in the city & $0.355(1.598)$ \\
& Binary variable for any Costcos in the city & $0.143(0.350)$ \\
Sam's Clubs & Number of Costcos in the county & $0.367(1.344)$ \\
& Number of Sam's Clubs in the city & $0.706(0.965)$ \\
& Sam's Clubs in the per 100,000 residents in the city & $0.608(0.884)$ \\
& Sam's Clubs per 100 square miles in the city & $1.254(2.035)$ \\
Supercenters & Binary variable for any Sam's Clubs in the city & $0.529(0.499)$ \\
& Number of Sam's Clubs in the county & $0.932(1.333)$ \\
& Number of Walmart Supercenters in the city & $0.730(1.119)$ \\
& Supercenters per 100,000 residents in the city & $1.041(1.835)$ \\
Discount Stores & Supercenters per 100 square miles in the city & $1.790(3.194)$ \\
Costco DC & Binary variable for any Supercenters in the city & $0.447(0.497)$ \\
Sam's DC & Number of Supercenters in the county & $1.073(1.845)$ \\
Supercenter DC & Number of Walmart discount stores in the city & $0.923(1.200)$ \\
Population & Miles to nearest Costco distribution center & $499.817(334.292)$ \\
Land & Miles to nearest Sam's Club distribution center & $260.890(184.949)$ \\
Income & Miles to nearest Walmart food distribution center & $297.910(319.851)$ \\
Grocery Stores & City population (units of 100,000) & $2.253(6.335)$ \\
Warehouse & City land area (units of 100 square miles) & $104.505(192.651)$ \\
clubs/supercenters & City median household income (units of 10,000) & $3.469(0.672)$ \\
& Number of grocery stores in the county & $77.152(173.277)$ \\
& Number of warehouse clubs or supercenters in the & $0.943(1.970)$ \\
& county (after subtracting Costcos, Sam's Clubs, and & \\
\hline & Walmart Supercenters) & \\
& & \\
& &
\end{tabular}


Table 5 - Baseline Results and Falsification Test

\begin{tabular}{|c|c|c|c|}
\hline & & Effect on Grocery Prices & $\begin{array}{c}\text { Effect on Non-Grocery } \\
\text { Prices }\end{array}$ \\
\hline \multirow[t]{2}{*}{ Costcos } & Short-Run Effect & $0.014(0.004)^{* * *}$ & $0.004(0.003)$ \\
\hline & Long-Run Effect & $0.027(0.008)^{* * *}$ & $0.011(0.008)$ \\
\hline \multirow[t]{2}{*}{ Sam’s Clubs } & Short-Run Effect & $0.003(0.004)$ & $0.004(0.004)$ \\
\hline & Long-Run Effect & $0.006(0.007)$ & $0.010(0.012)$ \\
\hline \multirow[t]{2}{*}{ Supercenters } & Short-Run Effect & $-0.009(0.001)^{* * *}$ & $-0.0007(0.001)$ \\
\hline & Long-Run Effect & $-0.017(0.003)^{* * *}$ & $-0.002(0.004)$ \\
\hline Lagged Price & & $0.472(0.009)^{* * *}$ & $0.636(0.013)^{* * *}$ \\
\hline Observations & & 70604 & 27657 \\
\hline
\end{tabular}




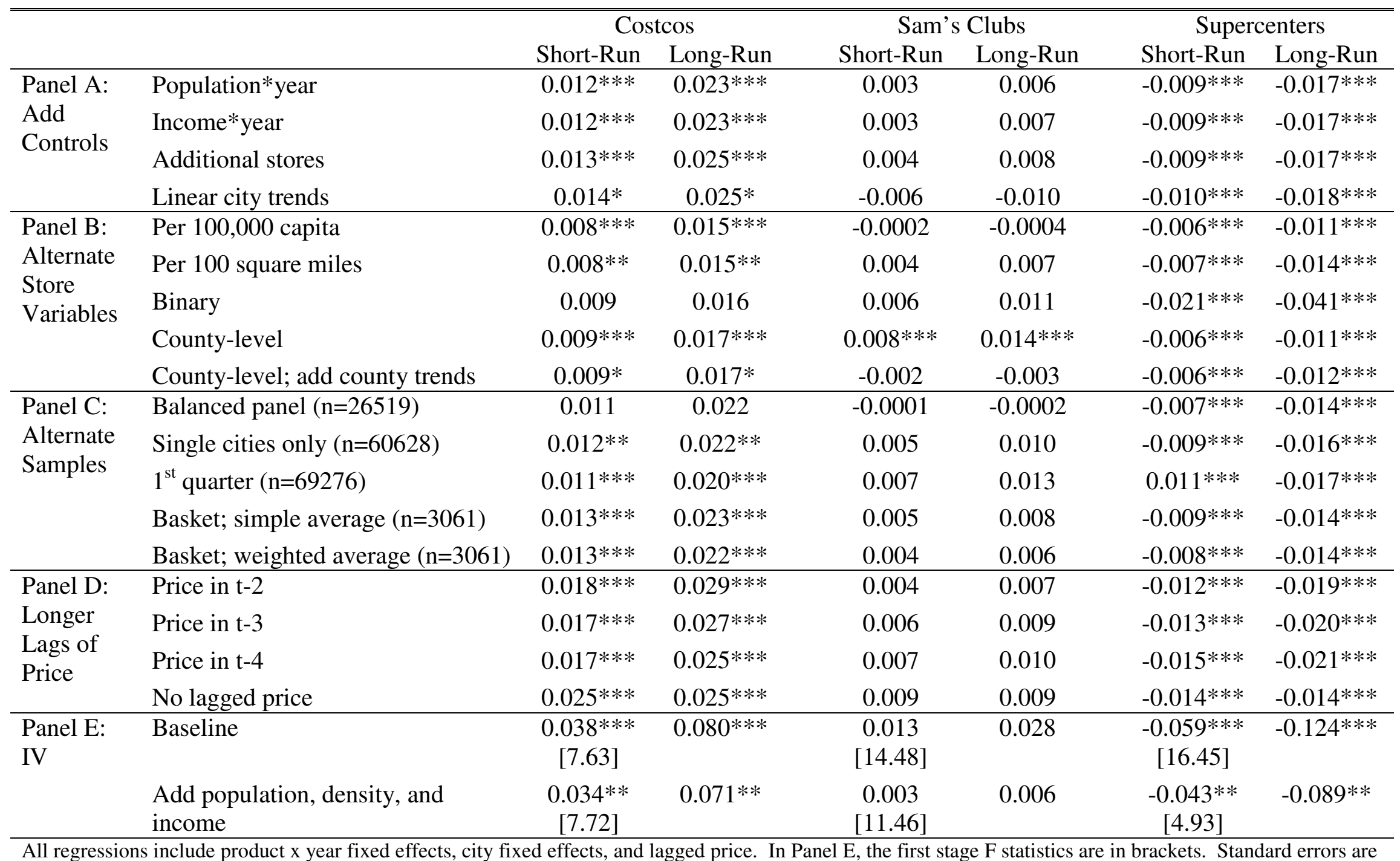

suppressed to save space; they are available upon request. See other notes for Table 5. 
Table 7 - Lags

\begin{tabular}{llccc}
\hline & & One Year Lag & Two Year Lag & Three Year Lag \\
\hline Costcos & Coefficient Estimate & $0.014(0.007)^{* *}$ & $0.013(0.006)^{* *}$ & $0.013(0.006)^{* *}$ \\
& Coefficient Estimate for Lag & $-0.0001(0.006)$ & $0.004(0.005)$ & $-0.003(0.006)$ \\
Sam's Clubs & Coefficient Estimate & $-0.003(0.005)$ & $-0.004(0.005)$ & $-0.003(0.005)$ \\
& Coefficient Estimate for Lag & $0.008(0.006)$ & $0.008(0.005)$ & $0.006(0.005)$ \\
Supercenters & Coefficient Estimate & $-0.011(0.003)^{* * *}$ & $-0.010(0.002)^{* * *}$ & $-0.009(0.002)^{* * *}$ \\
& Coefficient Estimate for Lag & $0.002(0.003)$ & $-0.0003(0.002)$ & $-0.00004(0.002)$ \\
Lagged Price & & $0.467(0.009)^{* * *}$ & $0.460(0.010)^{* * *}$ & $0.456(0.010)^{* * *}$ \\
Observations & & 65662 & 60487 & 55038 \\
\hline
\end{tabular}

See notes for Table 5 .

Table 8 - Leads

\begin{tabular}{llccc}
\hline \hline & & One Year Lead & Two Year Lead & Three Year Lead \\
\hline Costcos & Coefficient Estimate & $0.012(0.006)^{*}$ & $0.015(0.005)^{* * *}$ & $0.017(0.005)^{* * *}$ \\
& Coefficient Estimate for Lead & $0.004(0.005)$ & $-0.0006(0.004)$ & $0.0002(0.004)$ \\
Sam's Clubs & Coefficient Estimate & $-0.0006(0.006)$ & $0.0007(0.004)$ & $0.003(0.005)$ \\
& Coefficient Estimate for Lead & $0.005(0.005)$ & $0.008(0.004)^{* *}$ & $0.008(0.004)^{* *}$ \\
Supercenters & Coefficient Estimate & $-0.006(0.002)^{* * *}$ & $-0.008(0.002)^{* * *}$ & $-0.011(0.002)^{* * *}$ \\
& Coefficient Estimate for Lead & $-0.003(0.002)^{*}$ & $-0.002(0.002)$ & $-0.001(0.001)$ \\
Lagged Price & & $0.472(0.009)^{* * * *}$ & $0.471(0.009)^{* * *}$ & $0.481(0.009)^{* * *}$ \\
Observations & & 70674 & 65798 & 60646 \\
\hline
\end{tabular}

See notes for Table 5 . 
Table 9- Product Categories

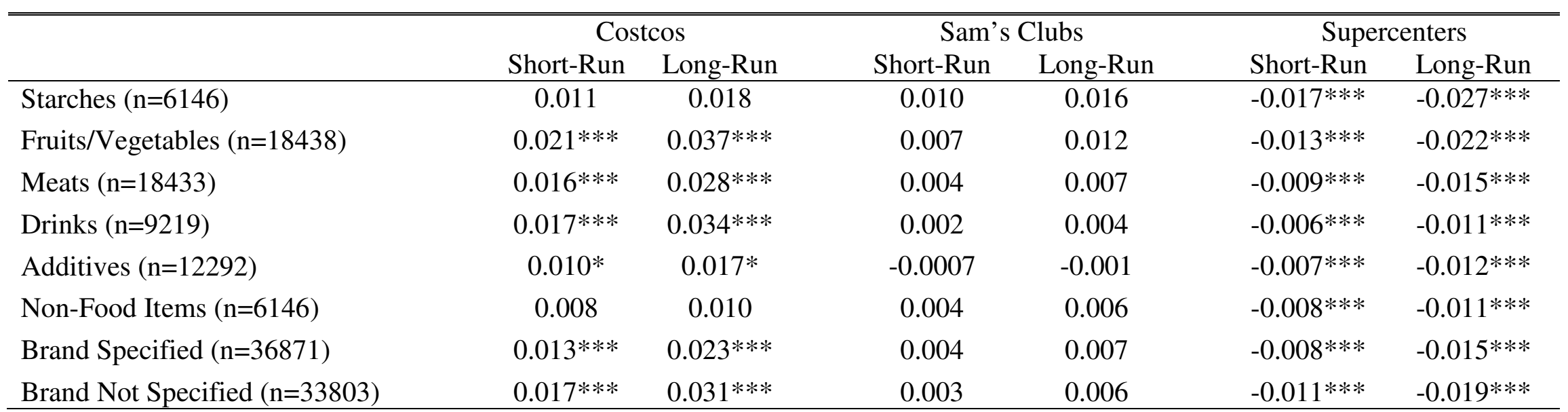

All regressions include product x year fixed effects, city fixed effects, and lagged price. Standard errors are suppressed to save space; they are available upon request. See other notes for Table 5. 
Table 10 - Individual Products

\begin{tabular}{|c|c|c|c|c|c|c|}
\hline & \multicolumn{2}{|c|}{ Costcos } & \multicolumn{2}{|c|}{ Sam's Clubs } & \multicolumn{2}{|c|}{ Supercenters } \\
\hline & Short-Run & Long-Run & Short-Run & Long-Run & Short-Run & Long-Run \\
\hline Bread & 0.007 & 0.008 & 0.012 & 0.015 & $-0.023 * * *$ & $-0.028 * * *$ \\
\hline Cereal & 0.021 & 0.028 & 0.017 & 0.023 & $-0.018 * * *$ & $-0.024 * * *$ \\
\hline Lettuce & $0.060 * * *$ & $0.066^{* * *}$ & 0.007 & 0.008 & $-0.017 * * *$ & $-0.026 * * *$ \\
\hline Bananas & 0.012 & 0.013 & 0.008 & 0.008 & $-0.017 * * *$ & $-0.018 * * *$ \\
\hline Potatoes & 0.018 & 0.019 & $0.048 * * *$ & $0.050 * * *$ & $-0.020 * * *$ & $-0.020 * * *$ \\
\hline Peas & $0.032 * *$ & $0.038 * *$ & 0.012 & $0.014 * *$ & $-0.017 * * *$ & $0.020 * * *$ \\
\hline Peaches & 0.013 & 0.018 & 0.011 & 0.016 & $-0.005^{*}$ & $-0.007 *$ \\
\hline Corn & $0.040 * * *$ & $0.049 * * *$ & -0.011 & -0.013 & $-0.022 * * *$ & $-0.027 * * *$ \\
\hline Steak & 0.018 & 0.020 & 0.001 & 0.001 & $-0.009 * *$ & $-0.010 * *$ \\
\hline Beef & $0.025 *$ & $0.028 *$ & $0.035 * *$ & $0.040 * * *$ & $-0.012 * *$ & $-0.013 * *$ \\
\hline Chicken & 0.024 & 0.027 & -0.006 & -0.007 & $-0.013 * * *$ & $-0.015 * * *$ \\
\hline Sausage & 0.017 & 0.018 & 0.008 & 0.009 & $-0.013 * * *$ & $-0.014 * * *$ \\
\hline Eggs & $0.035 * *$ & $0.038 * *$ & 0.007 & 0.007 & $-0.018 * * *$ & $-0.019 * * *$ \\
\hline Tuna & $0.027 * *$ & $0.032 * *$ & 0.003 & 0.004 & $-0.012 * * *$ & $-0.014 * * *$ \\
\hline Coffee & $0.026 * *$ & $0.031 * *$ & -0.006 & -0.007 & $-0.009 * * *$ & $-0.011 * * *$ \\
\hline Soft Drink & $0.027 * *$ & $0.033 * *$ & 0.012 & 0.015 & $-0.008 * *$ & $-0.010 * *$ \\
\hline Milk & $0.016 * *$ & $0.023 * *$ & 0.009 & $0.013 * *$ & $-0.007 * *$ & $-0.009 * *$ \\
\hline Sugar & $0.017 *$ & $0.019 *$ & -0.004 & $-0.004 *$ & $-0.006 *$ & $-0.006 *$ \\
\hline Shortening & 0.011 & 0.020 & $-0.011 * *$ & $-0.019 * *$ & $-0.004^{*}$ & $-0.006 *$ \\
\hline Parmesan & $0.019 * *$ & $0.029 * *$ & 0.008 & 0.011 & $-0.009 * * *$ & $-0.013 * * *$ \\
\hline Margarine & -0.003 & -0.003 & 0.013 & 0.016 & $-0.016 * * *$ & $-0.019 * * *$ \\
\hline Tissue & 0.001 & 0.002 & 0.011 & 0.013 & $-0.008 * * *$ & $-0.010 * * *$ \\
\hline Detergent & $0.015 *$ & $0.019 *$ & -0.00007 & -0.00008 & $-0.009 * * *$ & $-0.011 * * *$ \\
\hline
\end{tabular}

All regressions have a sample size of 3073 , except for sausage for which five observations are missing. All regressions include lagged price, product x year fixed effects, and city fixed effects. See other notes for Table 5. 
Table 11 - Heterogeneity by Order of Store

\begin{tabular}{|c|c|c|c|c|c|c|}
\hline & \multicolumn{2}{|c|}{ Costcos } & \multicolumn{2}{|c|}{ Sam's Clubs } & \multicolumn{2}{|c|}{ Supercenters } \\
\hline & Short-Run & Long-Run & Short-Run & Long-Run & Short-Run & Long-Run \\
\hline 1st Store & $0.012 * *$ & $0.023 * *$ & $0.008^{*}$ & 0.015 & $-0.013 * * *$ & $-0.025 * * *$ \\
\hline 2nd Store & $0.013 * *$ & $0.026 * *$ & 0.004 & 0.008 & $-0.011 * * *$ & $-0.021 * * *$ \\
\hline 3rd Store & $0.015^{*}$ & $0.029 *$ & 0.0003 & 0.0006 & $-0.009 * * *$ & $-0.017 * * *$ \\
\hline 4th Store & 0.017 & 0.031 & -0.003 & 0.006 & $-0.006 * * *$ & $-0.012 * * *$ \\
\hline $\begin{array}{l}\text { Estimates co } \\
\text { price, produ } \\
\text { available up } \\
\text { Costco } 0.012 \\
(0.002) \text {, Sup }\end{array}$ & $\begin{array}{l}\text { quest. See oth } \\
07), \text { Costco }^{2} \\
\text { ters }^{2} 0.001\end{array}$ & $\begin{array}{l}\text { ons of } \ln (\text { Pric } \\
\text { and city fixe } \\
\text { notes for Tab } \\
007(0.002), \\
03) \text {. }\end{array}$ & $0.010(0.00$ & $\begin{array}{l}\text { tores and the } \\
\text { rrors are sup } \\
\text { mates (stand } \\
\text { Sam's }{ }^{2}-0.00\end{array}$ & 05), Superce & $\begin{array}{l}\text { for lagged } \\
\text { they are } \\
\text { e variables: } \\
\text { ers }-0.015\end{array}$ \\
\hline
\end{tabular}




\section{Figure 1 - Marginal Effect of Costcos on $\ln ($ Price) by Population}

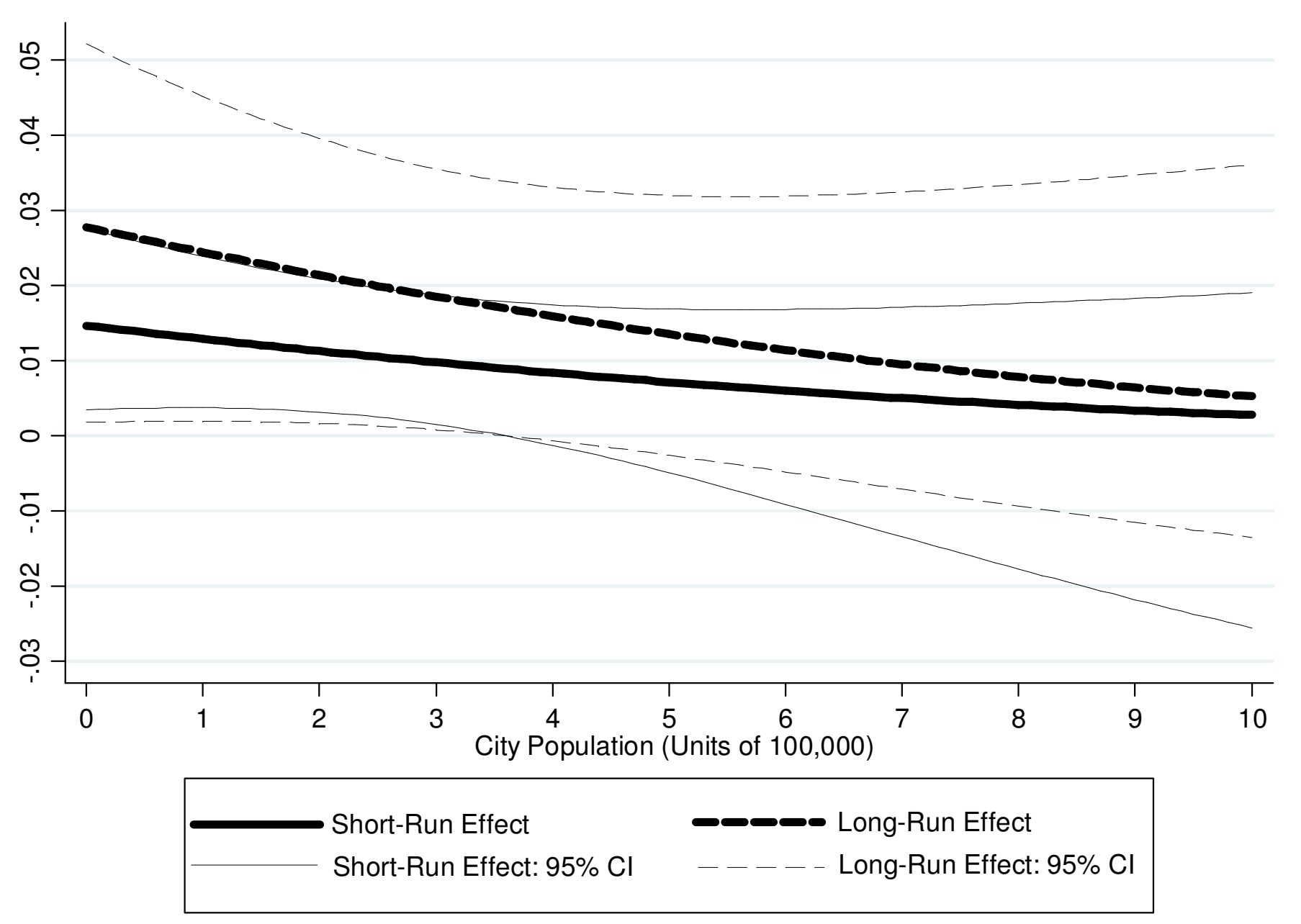

Coefficient estimates (standard errors): Costcos 0.015 (0.007), Costcos*population -0.0018 (0.0015), Costcos*population ${ }^{2} 0.00006$ (0.00004). 


\section{Figure 2 - Marginal Effect of Sam's Clubs on $\ln ($ Price) by Population}

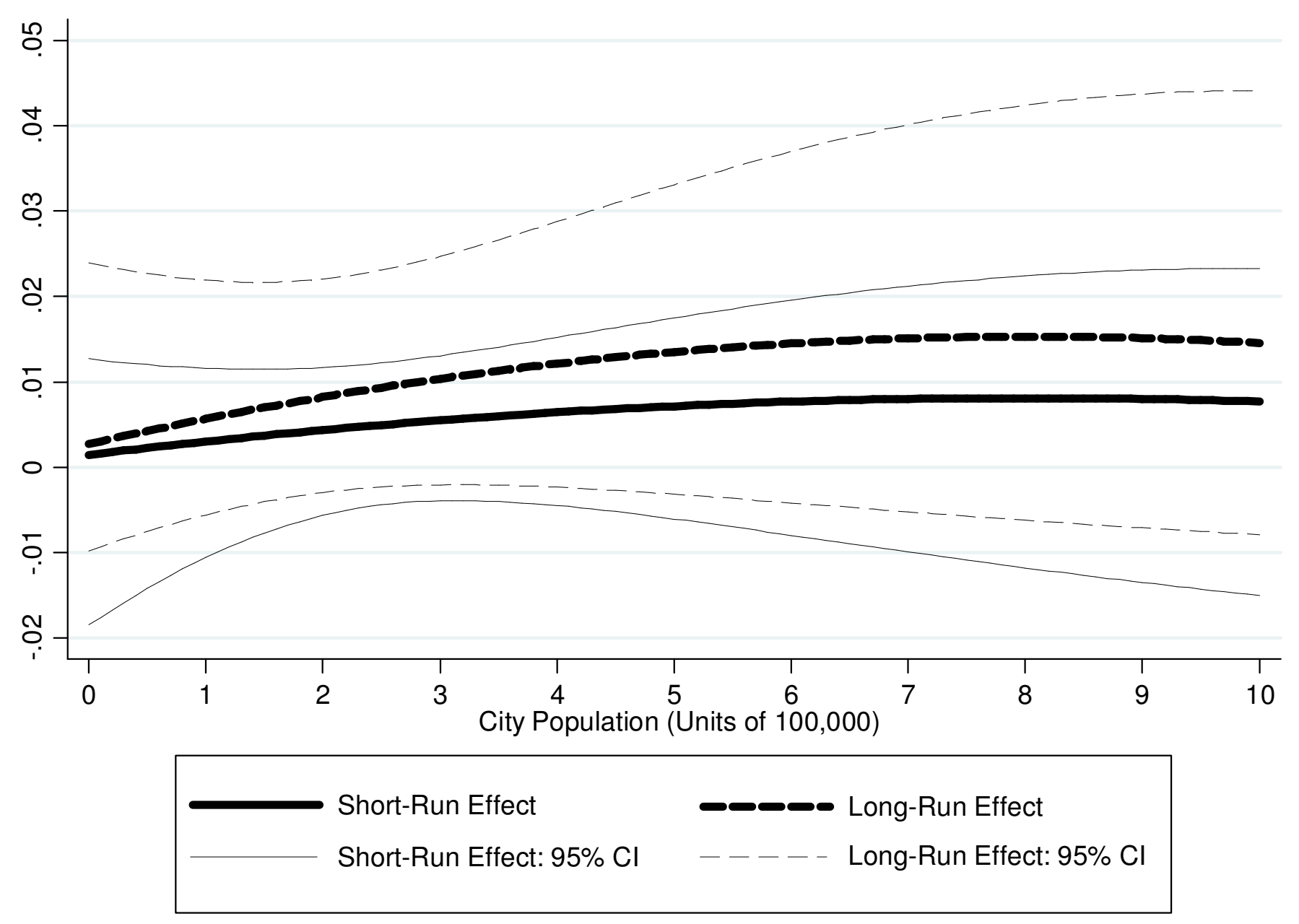

Coefficient estimates (standard errors): Sam's 0.001 (0.006), Sam's*population 0.002 (0.002), Sam's*population ${ }^{2}-0.0001(0.0001)$. 


\section{Figure 3 - Marginal Effect of Walmart Supercenters on $\ln ($ Price) by Population}

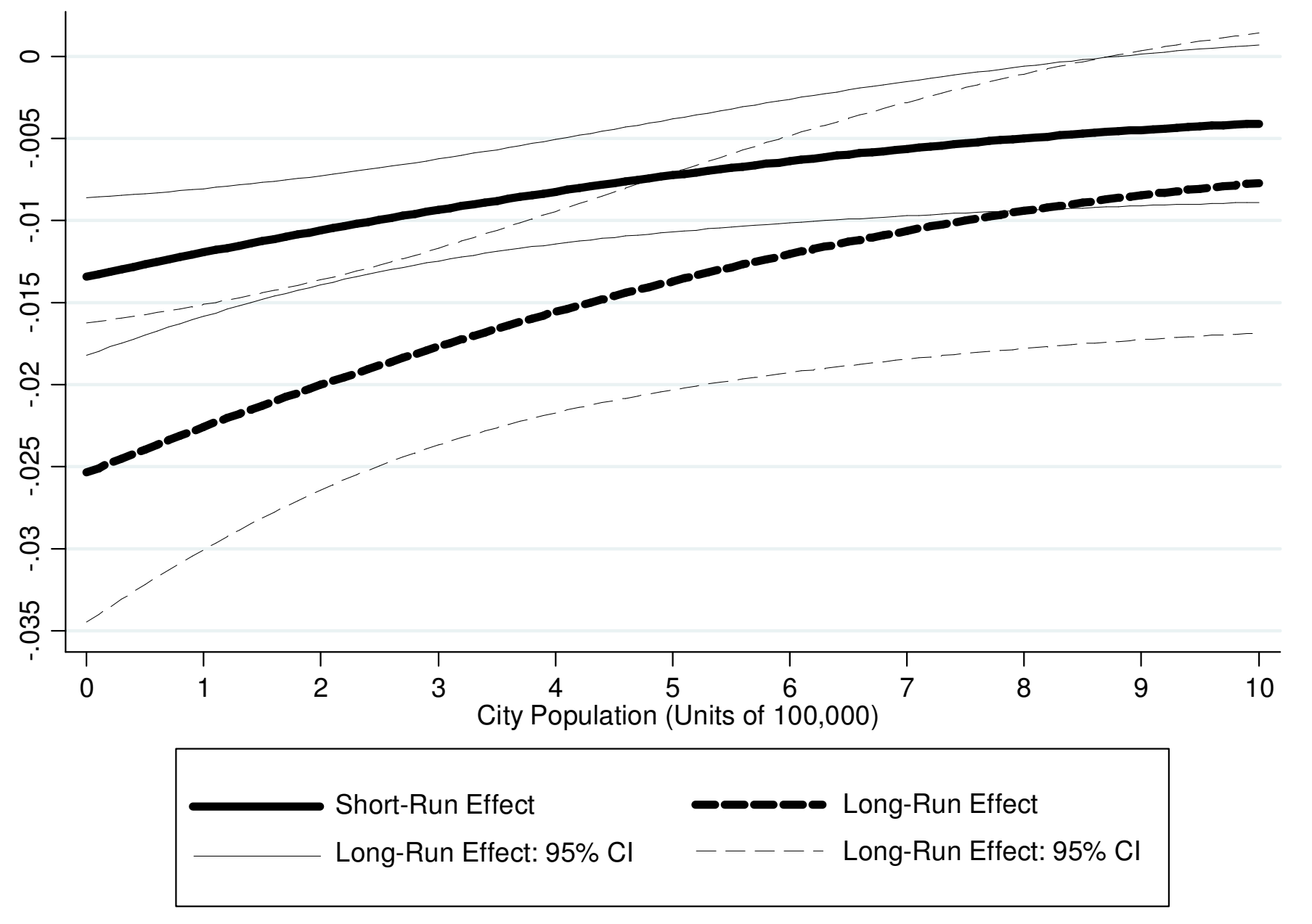

Coefficient estimates (standard errors): Supercenters -0.013 (0.002), Supercenters*population 0.0015 (0.0007), Supercenters* population $^{2}-0.00006(0.00004)$. 


\section{Figure 4 - Marginal Effect of Costcos on $\ln ($ Price) by Grocery Store Density}

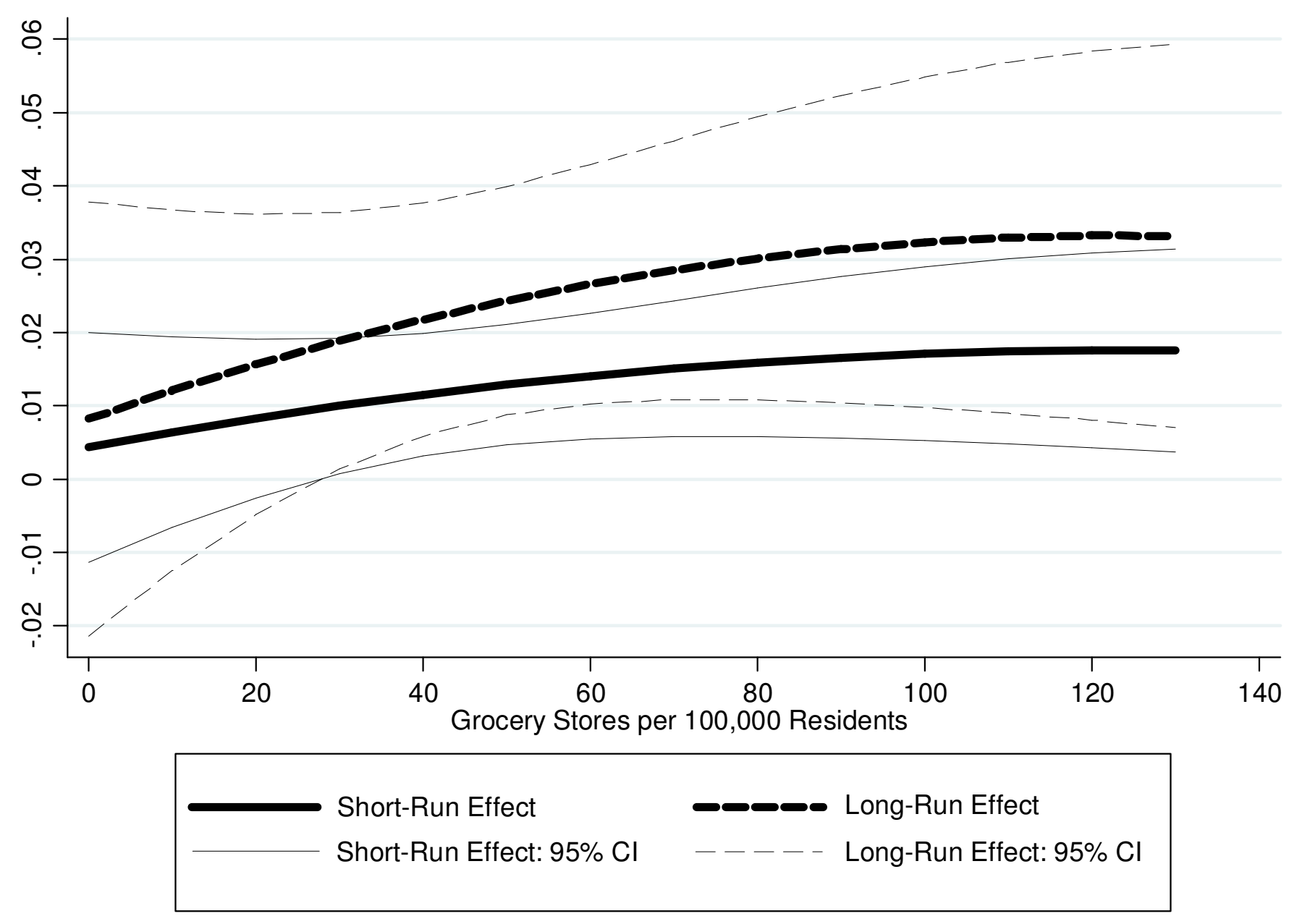

Coefficient estimates (standard errors): Costcos 0.004 (0.008), Costcos*stores 0.0002 (0.0002), Costcos*stores ${ }^{2}$-8.27e-7 (6.70e-7). 


\section{Figure 5 - Marginal Effect of Sam's Clubs on $\ln ($ Price) by Grocery Store Density}

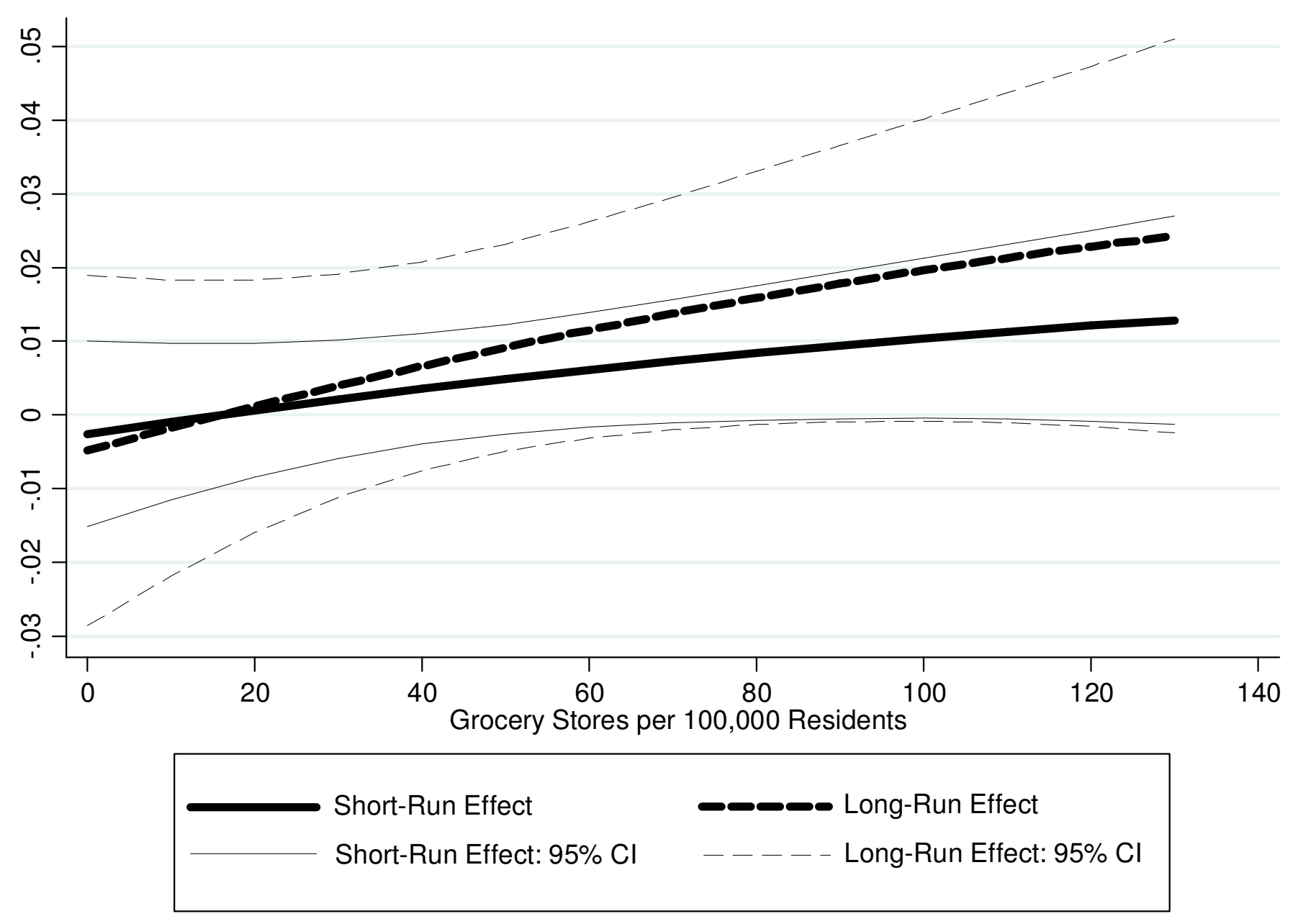

Coefficient estimates (standard errors): Sam's -0.003 (0.006), Sam's*stores 0.0002 (0.0001), Sam's*stores ${ }^{2}-3.70 \mathrm{e}-7$ (6.88e-7). 


\section{Figure 6 - Marginal Effect of Walmart Supercenters on In(Price) by Grocery Store Density}

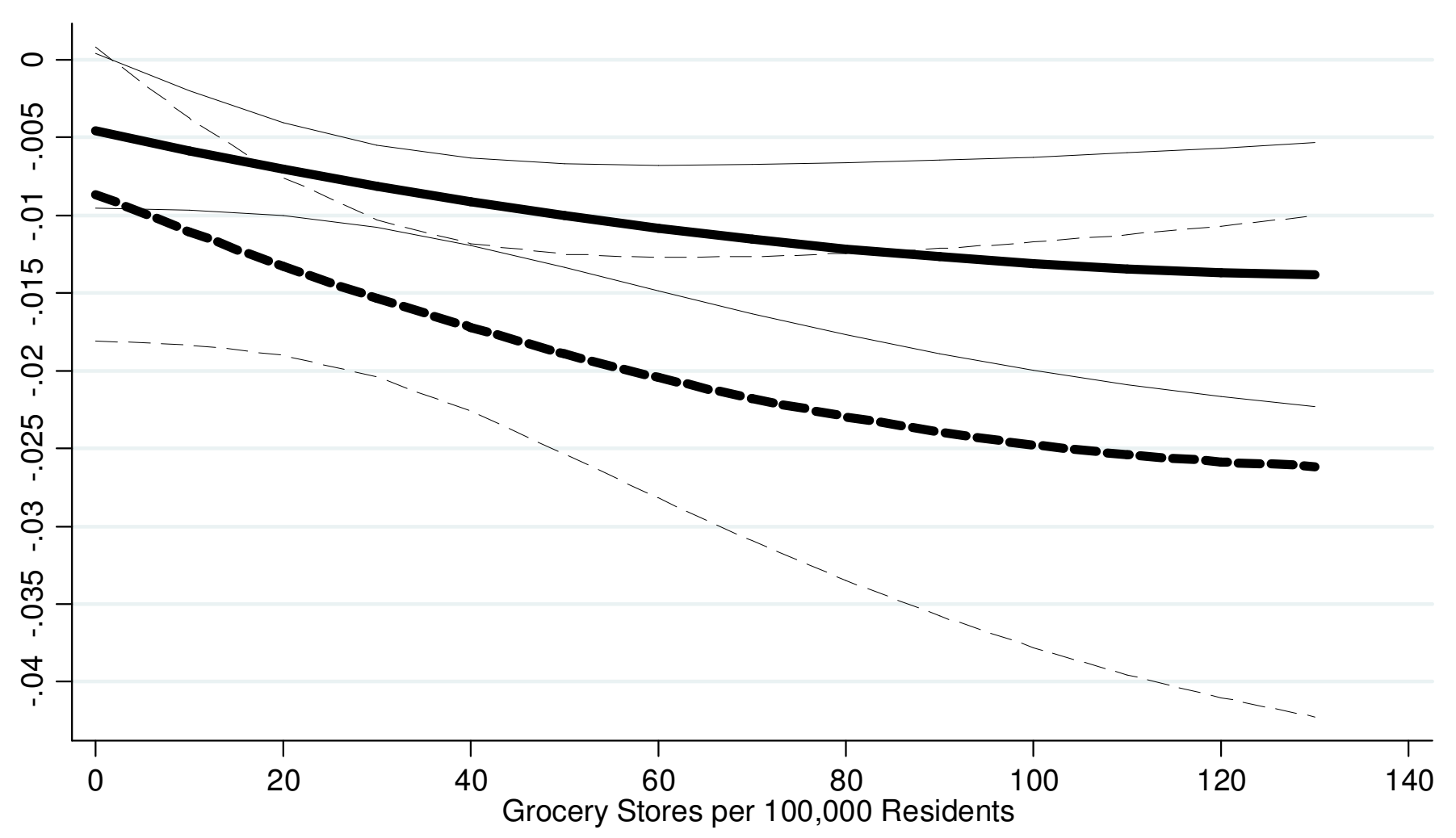

Short-Run Effect

Long-Run Effect

Short-Run Effect: $95 \% \mathrm{Cl}$

- - - - Long-Run Effect: 95\% Cl

Coefficient estimates (standard errors): Supercenters -0.005 (0.003), Supercenters* ${ }^{*}$ stores -0.0001 (0.00007), Supercenters*stores ${ }^{2}-4.70 \mathrm{e}-7$ (2.61e-7). 